Найдьонов Іван Миколайович кандидат педагогічних наук, доцент, професор МКА МАУП, вул. Фрометівська 2, м. Київ, 03039, тел.: (050) 71972-16, e-mail: ivan1942@ukr.net, https://orcid.org/0000-0003-3530-7582

\title{
НАЙВАЖЛИВІША ПЕДАГОГІЧНА ПРОБЛЕМА СУЧАСНОГО МЕНЕДЖМЕНТУ ДИСТАНЦЙНОЇ ОСВІТИ
}

Анотація. У статті розглядаються сучасні психолого-педагогічні проблеми педагогічного процесу формування особистості нової історичної епохи, компоненти та елементи дистанційного менеджменту надання освітніх послуг. Проаналізовано суттєві та змістовні характеристики основних компонентів та елементів менеджменту виховання в процесі дистанційної освіти. Обгрунтована перспективність дистанційної освіти у розвитку людини, незважаючи на заклики повернення до традиційного менеджменту надання освітніх послуг та продемонстровані під час пандемії обмеження і слабкі сторони онлайн-освіти.

Розглянуті методологічні засади управління на даному етапі людського планетарного розвитку, який характеризується бурхливим досягненнями в галузях науки та техніки, необмеженими можливостями Інтернету, створенням науковцями все нових і нових інтелектуально запрограмованих роботів, що вимагає від педагогічної науки вдосконалення методологічних основ процесу формування і становлення сучасного етапу менеджменту надання освітніх послуг в закладах освіти.

Розкрита управлінська діяльність, а також підходи рішення проблем єдності таких основних категорій педагогіки як навчання і виховання в процесі здобуття дистанційної освіти. Передбачено, що може прийти час появи в торгових мережах штучного інтелекту сімейних роботів-педагогів у сфері тієї чи іншої освіти. Доведено, що людську особистість дистанційно навчити можна, а щоб виховати необхідна активна діяльність вихователів.

Надана характеристика не тільки проблем виховання при дистанційному наданню освітніх послуг, але і визначені основні технологічні, методичні елементи самого виховного процесу при дистанційному наданні освітніх послуг в закладах освіти. Підкреслено, що технологічні етапи виховання, 3 точки зору фізіологічного розвитку особистості залишаються, але враховується процес урбанізації, вікові аспекти життєдіяльності тощо. У той же час тенденції розвитку виховного процесу у навчальних закладах, визначаються розвитком i функціонуванням державного управління, соціальними та економічними процесами в суспільстві.

Серед основних педагогічних компонентів виховного процесу надання освітніх послуг, особлива вага в статті надається індивідуальним формам виховання особистості, їх актуальності в сучасних умовах освіти в 
навчальних закладах. Розкриваються специфічні особливості класичних груп методів виховного процесу, з точки зору дистанційного навчання, дана характеристика їх моделі.

Ключові слова: педагогічні категорії, менеджмент дистанційної освітніх послуг; принципи, організаційні форми, методи, засоби менеджменту виховання в процесі надання освітніх послуг; суб'єкти менеджменту виховання у діяльному змісті освітнього процесу.

Naidonov Ivan Mykolaiovych Candidate of Pedagogic Sciences, Associate Professor, Prof. of IAPM, Frometivska St. 2, Kyiv, 03039, tel.: (050) 719-72-16, e-mail: ivan1942@ukr.net, https://orcid.org/0000-0003-3530-7582

\section{THE MOST IMPORTANT PROBLEM OF MODERN DISTANCE EDUCATION MANAGEMENT}

Abstract. Modern psychological and pedagogical problems of personality formation in the new historical epoch were investigated in the paper. Components and elements of remote management of educational services were studied. The essential characteristics and main components of the distance education management were analyzed. Despite the calls for a return to the traditional educational service management and the limitations of online education demonstrated during the pandemic, the prospects of distance education and its important role in human development were highlighted.

Methodological principles of management at this stage of human development were considered. The latter is characterized by rapid advancements in science and technology, unlimited potential of the Internet, development of robotics and AI. These processes require pedagogical science to focus on improving the methodological foundations of educational services management in educational institutions.

Management activity was studied and potential approaches to solving the problems of teaching and nurturing unity in distant education process were presented. The time may come when AI-driven robots will serve as instructors in some spheres of education. However, while it is easy to teach, it is a great challenge to nurture human personality. It was proven that nurturing requires human educators and mentors.

Not only was a problem of nurturing during distant education process defined, but also the basic technological, methodical elements of providing distant education services were highlighted. It was emphasized that while the technological stages of nurturing remain intact and defined by individual physiological development, but the processes of urbanization, age aspects of life should also be taken into account. At the same time, trends in the educational process development in institutions are determined by public administration, social and economic processes in society.

Among the main components of distant education services, the importance of individual forms of personality nurturing $\mathrm{w}$ emphasized. The specific features of 
classic methods of nurturing process were presented from the perspective of distant education.

Keywords: pedagogical categories, distant education management; principles, organizational forms, methods, means of nurturing in the education process, subjects of nurturing in the education process.

Постановка проблеми. Нові реалії педагогічного процесу дистанційного надання освітніх послуг в Україні XXI століття, гостро поставили завдання наповнення його духовним та інтелектуальним змістом. Педагогічна наука і практика сьогодні довели, що серед актуальних проблем освітнього процесу сьогодні найбільш привертає увагу педагога до виконання ним виховних функцій, які забезпечують можливість успішної організаційно-педагогічної діяльності в закладі освіти. Що дозволяє говорити про виховну діяльність фахівців і педагогічного колективу загалом, в дидактичному процесі надання освітніх послуг [1].

Науковці підкреслюють, що становлення особистості завжди відбувається у взаємодії окремої людини 3 мікро - та макросоціумом, тобто матеріальним і культурним середовищем, а також у взаємодії з різними соціальними інститутами, зокрема, 3 сім'єю, громадою, релігійними спільнотами, формальними чи неформальними об'єднаннями [2;3;4].

Основні педагогічні категорії навчання i виховання набувають ефективності в освітньому процесі становлення особистості, тільки в діалектичній єдності. У той же час домінант сучасної освіти у навчальних закладах здебільшого діє як консервативний «розподільник» відповідних знань, за якими губиться духовна складова особистості. Соціальноекономічний, науково-технічний і культурний планетарний розвиток людства вимагає від закладів освіти сформувати у молоді не лише грунтовні фахові знання, а й високу духовні, гуманні морально-етичні якості. Назване дає змогу окреслити низку суперечностей в виховному процесі при наданні освітніх послуг:

- між потребою сучасного суспільства у вихованні гуманної, високодуховної людини і низьким рівнем гуманізму i духовності нашого суспільства;

- між об’єктивною потребою суспільства в формуванні сучасного громадянина здатного до суспільно-практичної діяльності і не розробленістю конкретної технології і методики виховання молоді в умовах дистанційного надання освітніх послуг;

- між необхідністю розкриття і розвитку виховного потенціалу молодого покоління і відсутністю у нього усвідомлених знань щодо значення ролі виховання у життєдіяльності і подальшій еволюції людини і людства;

- між більш чи менш виразним аксіологічним потенціалом кожної навчальної дисципліни освітнього закладу у формуванні вихованості особистості, і надмірним «переважанням» в освітньому процесі конкретних знань з того чи іншого предмету без урахування їх виховного потенціалу; 
- між необхідністю у змісті освіти знаходити відповідне місце вихованню особистості, яка усвідомлює свою роль у життєдіяльності суспільства і відсутністю відповідних навчальних дисциплін, зміст яких був би спрямований конкретно на виховний процес.

Аналіз останніх досліджень та публікацій. Відомо, що виховання особистості - багатоаспектна проблема, яку досліджує багато вітчизняних та зарубіжних учених. Предметом уваги дослідників $є$ сутність виховання i розвитку особистості, менеджменту організації в формуванні їі духовних потреб, самореалізації морально-етичних та культурологічних якостей.

Загальний філософський аспект, психолого-педагогічні напрями дослідження феномена виховання сучасної людини, глибоко, грунтовно i всебічно висвітлені у працях відомих українських науковців. Зокрема, I. Бехом, М. Боришевським, Г. Баллом, В. Баранівським. М. Свтухом, В. Жуковським, І. Зязюн, В. Кременем, А. Мінаковим, В. Москальцем, Г. Назаренко, М. Савчиним, В. Сухомлинським, О. Сухомлинською, О. Савченко, Т. Цюман та ін.

Про це свідчать і останні дослідження виховного процесу в закладах освіти. Так, С. В. Жученко розглядає проблеми теорії та методики моральноестетичного виховання студентської молоді на основі цілісного, системного та комплексного підходів, інтеграції дисциплін культурологічного, гуманітарного та природничого циклу, у поєднанні з виховною діяльністю вихователів-менеджерів. Визначає основні блоки процесу та його критерії (Дисертація «Виховання морально-естетичної культури у студентів технічних коледжів» .- Сєверодонецьк.: 2017.- 287 с.).

Проблеми діагностики виховання засобами освітнього тренінгу як загалом, так і у процесі формування культури життєвого самовизначення старшокласників, розкриває у дисертаційному дослідженні науковець Т.П. Цюман. Узагальненні в роботі основні компоненти та елементи освітнього тренінгу, його структура, механізми знаходять своє місце в діяльному компоненті менеджменту виховання особистості, при дистанційному наданні освітніх послуг у навчальному закладі.

Духовно-моральне виховання дітей у вітчизняній школі достатньо широко обгрунтовує у монографії І. Л. Сіданіч. Суттєво і змістовно визначені в роботі провідні тенденції та особливості розвитку духовно-морального виховання дітей у вітчизняній школі в умовах сучасного суспільства, мають відповідне значення в процесі дистанційного надання освітніх послуг [5].

Заслуговують значної уваги теоретичні та методичні узагальнення технології, методики процесу виховання у школярів ціннісного ставлення до людини в монографії О. В. Столяренко ([Монографія]. Кн. 2. Методологія виховання ціннісного ставлення до людини в учнів загальноосвітньої школи /- Вінниця: ТОВ «Нілан-ЛТД», 2018. - 408 с.).

У напрямі дослідження проблем навчання i виховання в освітньому процесі важливе значення має діяльність педагогів-менеджерів школи професора Тетяни Дмитрівни Кочубей. Актуальність та доцільність їх успішного розв'язання сприятимуть подальшому розвитку вітчизняної 
практичної технології, методики виховання майбутніх громадян XXI століття.

Перелік наукових досліджень процесу виховання молоді у закладах освіти можна продовжити. Але конкретно виховання, в умовах дистанційного надання освітніх послуг, ще не знайшло значного висвітлення в дисертаційних дослідженнях, публікаціях наукових журналів.

Мета статті. Показ першочергової необхідності дослідження проблеми виховання при дистанційному наданні освітніх послуг у навчальних закладах, здійснення аналізу суттєвих та змістовних характеристик основних компонентів та елементів менеджменту виховання у процесі дистанційної освіти, окреслення його суперечностей і моделі.

Виклад основного матеріалу. Виховання в освітніх закладах завжди були предметом уваги держави і суспільства. Про це свідчать законодавчі та нормативні документи висвітлені в Конституції України, Законі України «Про освіту», відповідних Положеннях про освітню діяльність закладів освіти. Верховна Рада України на своїх слуханнях по проблемним питанням виховання молоді рекомендувала Міністерству освіти i науки України вжити заходів щодо вдосконалення роботи 3 патріотичного, правового, морального, екологічного виховання дітей та молоді, формування у них моральних цінностей, соціальної активності та громадянської відповідальності, утвердження здорового способу життя [1; 6].

В сучасних умовах дистанційного надання освітніх послуг, процес виховного впливу педагога-менеджера здійснюється в режимі спілкування, 3 використанням більш-менш апробаційних форм педагогічного процесу. Серед них чільне місце займають наступні: електронна пошта (передача передавання повідомлень у формі звичайних текстів); форум (звичайне проблемне спілкування у відкритому чи зашифрованому вигляді); відео конференція (здійснюється в реальному часі в on-line режимі); блог (процес колективного спілкування); чат (засіб оперативного спілкування людей через Інтернет), ін. Використання названих, інших форм надання освітніх послуг не тільки надає можливість педагогу-менеджеру контролювати, систематизувати, оцінювати діяльність, переглядати результати виконаних завдань, але і здійснювати виховний вплив на особистісну емоційно-вольову сферу суб'єктів учіння. Своєю участю в різних формах взаємодії він їм показує, що присутній, цікавиться ними, уважний і моніторить їх освітню діяльність.

Отже, спілкування при дистанційній освіті виступає як технологічний i спеціальний, методично цілеспрямований процес організації і стимулювання виховної пізнавальної діяльності суб'єктів учіння, що формує діалектичне та гнучке світорозуміння ціннісних орієнтацій; емоційної культури, вольової саморегуляції поведінки, здатності до самопізнання та самоосвіти; умінь та навичок високоморальної діяльності та духовно-моральної практики.

Але спілкування, як технологічний напрям у виховному процесі дистанційного надання освітніх послуг вимагає відповідних методів та засобів впливу. Якщо говорити про методи, на нашу думку, в основному, 
сьогодні, це - методи впливу на свідомість і почуття особистості. Вони здійснюють, в основному, словесний вплив на особистість, і передбачають прості навчально-виховні форми: метод бесіди, розповіді, лекції, диспуту, прикладу [7].

Аналіз літературних джерел, практика навчально-виховного процесу в освітніх закладах дає можливість стверджувати, що методика виховання у процесі дистанційного надання освітніх послуг у закладах освіти - це творчий процес, який передбачає у відповідності 3 цілями, на основі дидактичних закономірностей i принципів сукупність форм, методів, прийомів виховної діяльності педагогів-менеджерів. Вона виступає внутрішнім педагогічним регулятором, який визначає та розробляє тактику виховання, тобто переводе освітній процес у русло конкретної виховної діяльності у формі програм, планів, технологічних дій, рекомендацій. Методика виховного впливу на особистість суб'єкта учіння, повинна бути центральним блоком у сучасному процесі дистанційного надання освітніх послуг [8].

Основна мета методики виховного впливу, в процесі управління дистанційним здобуттям освіти суб'єктами учіння, це - допомогти в цей період педагогу-менеджеру оволодіти технологією та методикою ефективної організації вихованої діяльності. Бажано пам'ятати, що ще у свій час А.С. Макаренко метод виховання назвав «інструментом дотику до особистості». Тому, спираючись на класичні дидактично-виховні педагогічні компоненти, для ефективної реалізації виховної мети, в процесі дистанційної освіти, необхідно обгрунтувати ряд концепцій та програм розвитку освіти, які повинні передбачати: досягнення фундаментальності знань суб'єктами учіння; створення умов для розвитку їх творчо - самостійної роботи; забезпечення готовності майбутніх громадян до самостійного розв'язання нагальних життєвих завдань; розширити зміст екологічних елементів освіти [9].

Для реалізації мети бажано конкретизувати, відповідно до нових умов, специфічні методологічні підходи педагогів-менеджерів в процесі надання освітніх послуг. Серед них вагоме місце займають наступні:

- особистісний, в умовах дистанційного надання освітніх послуг, в першу чергу передбачає опору на природний процес саморозвитку суб'єкта учіння, його самореалізацію, самоствердження, в той же час, створення для цього відповідних умов;

- діяльний, спрямований на організацію морально-етичної життєдіяльності суб'єкта, яка б забезпечувала його активність у пізнанні, праці, спілкуванні, саморозвитку;

- системний, який орієнтує на визначення навчання i виховання як цілеспрямовану творчу діяльність його основних суб'єктів, основні компоненти мета якої взаємопов'язані;

- гуманно - гуманістичний, який передбачає започаткування належного місця навчальним дисциплінам гуманітарного напрямку, духовно-особистісну спрямованість кожного навчального предмета, формування відносин 
суб'єктів учіння у середовищі життєдіяльності на основі поваги, довіри, чуйності, доброзичливості, уваги, співчуття;

- ресурсний - зосередження педагога-менеджера на питаннях організації освіти, орієнтованої на виявлення і розвиток потенційних розумових та морально-етичних можливостей кожного суб'єкта учіння;

- синергетичний - організаційно-прикладний процес формування у суб'єктів учіння потягів до самостійної реалізації і саморозвитку їх загальнолюдських морально-етичних якостей, на основі постійної взаємодії 3 педагогом-менеджером, навколишнім середовищем;

- аксіологічний - діагностично-прикладний процес виявлення у суб'єктів учіння можливостей задовольняти свої загальнолюдські морально-етичні потреби, розв’язувати завдання гуманізації в середовищі життєдіяльності, наявному суспільстві, формувати для цього відповідні потяги;

- компетентний - діагностика аксіологічного мотивування, рефлексивних, когнітивних, операційно - технологічних та інших результатів освіти, які відображають розширення не тільки знань, умінь і навичок, а й досвіду ціннісного емоційного, морально-етичного ставлення до дійсності.

Названі підходи до освіти передбачають і відповідні специфічні форми виховної діяльності педагогів-менеджерів, а також технологію і методику їх застосування. Сучасна особистість, як суб’єкт учіння, вимагає не просто методів формування свідомості (бесіда, розповідь чи цікавий приклад), але i їх емоційного впливу, шляхом відповідних засобів, таких наприклад, які використовуються у шоу-бізнесі. А здійснити такий виховний вплив можливо за допомогою методів організації діяльності та стимулювання поведінки і діяльності особистості суб'єкта учіння.

Відомо, що в класичній педагогіці розглядаються прості і комплексні форми виховного процесу. Серед простих виділяється така організована форма, яка передбачає цілеспрямоване дійство в основі якого знаходиться інтелектуальна суперечка між вихованцями, які мають різні погляди на відповідну проблему, тобто диспут. Враховуючи технологічні і методичні вимоги проведення, його можна проводити і при дистанційній освіті. Хоча ми погоджуємося з професором Даріуш Грзадзієл (Dariusz Grzadziel), який підкреслює, що педагог не може відкрити дискусію, а тоді забути про суб’єктів учіння, покинути їх, залишити, щоб лише самі між собою спілкувалися. Необхідно зазначити, що його ефективність буде залежати, як $\mathrm{i}$ іншої виховної форми, при дистанційному наданні освітніх послуг у закладах освіти, від уміння педагога-менеджера поєднати організацію та методику його підготовки і проведення. А це значить: чітке розуміння учасниками мети, завдань майбутньої виховної дії; органічне поєднання усіх видів діяльності учасників форуму, чи блогу, або відео конференції (пізнавальної, комунікативної, мотиваційної, психомоторної, регулятивної), які забезпечать творчість у самовдосконаленні відповідних якостей особистості; визначення емоційно-цікавого змісту, який буде забезпечувати виконання цільових завдань; підбір раціональних методів, засобів, прийомів впливу на свідомість та почуття вихованця з урахуванням цільових завдань, характеру аудиторії і 
реальних можливостей педагога-менеджера.

Важливе значення мають індивідуальні бесіди. Вони залежно від автентичного розвитку суб'єкта учіння, його інтуїтивно діючої інтенції (лат. intentio - устремління), можна класифікувати на: діагностуючі внутрішньо інтенцій ну спрямованість особистості, формуючі іiі вихідні ціннісні орієнтації, які слугують основою для вирішення головної життєвопедагогічної суперечності між власно особистісним «хочу» $\mathrm{i}$ загальносуспільним треба. У той же час, у залежності від конкретної ситуації та змісту вони можуть мати стратегічний та тактичний характер. Перші спрямовані на формування еко- психологічної системи, особливо суб'єктів учіння, що 3 часом стає їх внутрішнім переконанням, i які $\epsilon$ вихідною орієнтувальною основою життєдіяльності, особливо під час іiі дискомфортності. Другі виступають у ролі корегую чого педагогічного інструментарію. Прикладом можуть бути бесіди про природу добра у житті людини, про необхідність підготовки до освітніх занять, виконання життєво необхідних завдань тощо.

Сучасний процес виховання, при наданні освітніх послуг особливо вимагає застосування відповідних рис емоційного впливу і структурованості. Серед рис емоційного впливу вагоме місце займають: художність, образність, виразність. Структура в діяльності педагога-менеджера передбачає наступні структурні компоненти: цільовий (мета, завдання виховної діï); змістовний (композиційний устрій; гармонійне розміщення елементів змісту); характер аудиторії вихованців, а також у процесі дистанційного спілкування вигляд на екрані; стимулююча характеристика засобів емоційного i художнього впливу; оціночно-результативний (на рівні самооцінки організаторів і оцінки аудиторії).

Щодо третьої групи класичних методів, на нашу думку, бажано звернути увагу на методи заохочення і змагання. Вони більш суттєво закріплюють позитивні навички і звички діяльності і поведінки суб’ єктів учіння.

Із четвертої групи класичних методів виховання, при дистанційному наданні освітніх послуг бажано виділити наступні методи: методи педагогічного спостереження, бесіди, анкетування, незалежних характеристик, аналізу результатів виховання. При цьому важливо враховувати специфіку кожного методу при дистанційній освіті. Так, наприклад, застосовуючи метод спостереження, враховувати його види, структуру, фіксацію на різноманітних носіях: щоденник, короткі нотатки, картки.

Відомо, що метод узагальнення незалежних характеристик дозволяє поглянути на сферу спрямованості вихованця очима його друзів, батьків, колег по навчанню (роботі) тощо. Але важливо зіставляти та аналізувати отримані дані, з'ясовувати причини розбіжностей у судженнях, оскільки окремі із них можуть зумовлюватися поспішністю або необ'єктивністю суджень.

Ефективність виховного впливу педагогів-менеджерів, при дистанційній освіті значно залежить від їх уміння поєднати методи виховання i 
самовиховання особистості: самообов'язку, самозвіту, самоаналізу, самоконтролю і самооцінки. Але, аналіз літературних джерел, практика дистанційної освіти свідчить, про необхідність звернути увагу на методи виховання, обгрунтовані С.С. Пальчевським. Особливо на автосугестопедичні (самонвіювальні) методи, які поєднують класичні методи самовиховання на сугестивній основі, яка включає сугестивну настанову та навіювальні сили авторитету рідних та близьких людей, представників «світу великих людей», а також авторитету ідей, вчення, релігії, міфу тощо.

У цілому, на засадах цілісного, системного та комплексного підходів виникає необхідність теоретичного обгрунтування та впровадження моделі виховання суб'єктів учіння, в процесі менеджменту дистанційного надання освітніх послуг. Модель може складатися із наступних блоків: цільового, (загальна концепція, мета та завдання); теоретико-методологічного (наукові підходи: дисертаційні дослідження, автореферати, статті на основі обгрунтованих закономірностей i принципів функціонування цілісної системи виховання суб'єктів освіти); змістовно-технологічного (визначення змісту, форм, методів, засобів та педагогічних умов); критеріальнорезультативного (критерії, показники та рівні вихованості суб'єктів освіти в навчальних закладах).

Висновки. Отже, усе зазначене підводить до висновків:

1. Проблеми дослідження виховання в процесі дистанційного надання освітніх послуг в навчального закладах є надзвичайно актуальними.

2. Виникає необхідність розробки концепції управління виховним, культурологічним процесом при дистанційній освіті.

3. Важливим є гармонійне збалансування визначених із класичних форм, методів прийомів, основних технологічних, методичних елементів самого виховного процесу при дистанційному наданні освітніх послуг.

4. При дистанційній освіті серед основних компонентів, елементів культурно-виховного процесу, необхідно особливу увагу звернути на індивідуальні форми виховання особистості, їх актуальність, технологію, методику.

5. Запропонована теоретична модель виховання, при дистанційній освіті може бути ефективною за умов суспільно-державної підтримки, гуманітаризації та гуманізації освітнього процесу.

Таким чином, у подальшому розвитку менеджменту дистанційного надання освітніх послуг, уже розпочалася розробка різноманітних форм, методів виховання. Але необхідно завжди пам'ятати, що у процесі виховання не може бути стандартних ситуацій і стандартних підходів до використання способів виховного впливу. Тому, все назване передбачає наші подальші дослідження названої проблеми. I ми бажаємо, щоб в його аналізі, перспективі розвитку цього процесі прийняли участь науковці, на рівні дисертаційних досліджень, монографій. Переконані, що належна увага до виховання молоді, створення у стінах освітнього закладу відповідного культурно-виховного, методичного середовища, здатні забезпечити передбачуваний виховний вплив, при дистанційному наданні освітніх послуг. 


\section{Лimepamypa:}

1. Найдьонов I. М. Сучасний етап менеджменту надання освітніх послуг .SCIENTIFIC ACHIEVEMENTS OF MODERN SOCIETY Abstracts of XII International Scientific and Practical Conference Liverpool, United Kingdom 22-24 July 2020 Liverpool.2020.- C. 295-305.

2. Бех І.Д. Вибрані наукові праці. Виховання особистості. Том 2.- Чернівці: Букрек, 2015.- $640 \mathrm{c}$.

3. Дистанційне навчання як сучасна освітня технологія [Електронний ресурс] : матеріали міжвузівського семінару (м. Вінниця, 31 березня 2017 р.) . - Вінниця : ВТЕI КНТЕУ, 2017. - 102 c.

4. Найдьонов I.M. Психолого-педагогічні аспекти управління процесом впровадження інновацій при наданні освітніх послуг.// Матеріали V Міжнародної науковопрактичної конференції 19 березня 2020 р. Видавництво МАУП.- К.: 2020, с.193-197.

5. Сіданіч І. Л. Духовно-моральне виховання дітей у вітчизняній школі (XX початок XXI ст.): моногр. / І. Л. Сіданіч : НАПН України, Ун-т менедж. освіти. — К. : ТОВ «НВП» Інтерсервіс, 2013. - 464c.

6. Про Рекомендації парламентських слухань про становище молоді в Україні на тему «Ціннісні орієнтації сучасної української молоді». - Документ 1908-У111 від 23.02.2017.

7. Найдьонов I.M. Навчально-методичний комплекс дисципліни «Основи психології і педагогіки». Навч. посіб. - Вид. друге.- К., 2009.- 280 с.

8. Найдьонов I.М. Етика - естетика: дидактичний зміст: Навч. посіб. - К.: Кондор, 2011. -550 c.

9. Найдьонов I.M. Основи освітянського менеджменту: навч. посіб. / I.M. Найдьонов. - Київ: Міжрегіональна Академія управління персоналом, 2020.- Ч. 2.260 с.; Ч. 3.- 234 c.

\section{References:}

10. Najd'onov I. M. Suchasnij etap menedzhmentu nadannja osvitnih poslug .SCIENTIFIC ACHIEVEMENTS OF MODERN SOCIETY Abstracts of XII International Scientific and Practical Conference Liverpool, United Kingdom 22-24 July 2020 Liverpool.2020.- S. 295-305.

11. Beh I.D. Vibrani naukovi praci. Vihovannja osobistosti. Tom 2.- Chernivci: Bukrek, 2015.- $640 \mathrm{~s}$.

12. Distancijne navchannja jak suchasna osvitnja tehnologija [Elektronnij resurs] : materiali mizhvuzivs'kogo seminaru (m. Vinnicja, 31 bereznja 2017 r.) . - Vinnicja : VTEI KNTEU, 2017. - $102 \mathrm{~s}$.

13. Najd'onov I.M. Psihologo-pedagogichni aspekti upravlinnja procesom vprovadzhennja innovacij pri nadanni osvitnih poslug.// Materiali V Mizhnarodnoï naukovopraktichnoï konferenciï 19 bereznja 2020 r. Vidavnictvo MAUP.- K.: 2020, s.193-197.

14. Sidanich I. L. Duhovno-moral'ne vihovannja ditej u vitchiznjanij shkoli (HH pochatok HHI st.): monogr. / I. L. Sidanich : NAPN Ukraïni, Un-t menedzh. osviti. — K. : TOV «VP» Interservis, 2013. - 464s.

15. Pro Rekomendaciï parlaments'kih sluhan' pro stanovishhe molodi v Ukraïni na temu «Cinnisni orientaciï suchasnoï ukraïns'koï molodi». - Dokument 1908-U111 vid 23.02.2017.

16. Najd'onov I.M. Navchal'no-metodichnij kompleks disciplini «Osnovi psihologiï i pedagogiki». Navch. posib. - Vid. druge.- K., 2009.- 280 s.

17. Najd'onov I.M. Etika - estetika: didaktichnij zmist: Navch. posib. - K.: Kondor, 2011. $-550 \mathrm{~s}$.

18. Najd'onov I.M. Osnovi osvitjans'kogo menedzhmentu: navch. posib. / I.M. Najd'onov.

- Kiïv: Mizhregional'na Akademija upravlinnja personalom, 2020.- Ch. 2.- 260 s.; Ch. 3.- 234 s. 